\title{
Editorial August 2016: Forward to WAC Kyoto!
}

\author{
John Carman, Ironbridge International Institute for Cultural Heritage, School of \\ History and Cultures, College of Arts and Law, University of Birmingham, ERI Building, \\ Edgbaston, Birmingham, B15 2T, UK \\ E-mail: j.carman@bham.ac.uk
}

Jan Turek, Czech Institute of Egyptology, Charles University, Prague, Czech Republic E-mail: turekjan@hotmail.com

This year, the founding organisation of this journal, the World Archaeological Congress, celebrates its 30th anniversary. We look forward to greeting colleagues old and new from all across the world and at all stages in their careers in Kyoto from August 28th. The resilience of the organisation over the past three decades is testimony to the need of the archaeological community worldwide for an organisation that reflects at once the diversity and the unity of our calling. The focus of WAC in emphasising the political and ethical role played by archaeology in the contemporary context has been especially important in the development of the discipline worldwide. The WAC practice of holding congresses in parts of the world major global conferences had until then rarely reached-especially Venezuela in 1990, India in 1994, South Africa in 1999, and Jordan in 2013-has encouraged international collaborations between workers in very diverse territories, especially as represented in the publications that have emerged from those Congresses.

The content of this issue reflects some of the central concerns of WAC and its commitment to developing the field. Collectively, they look forward-one way and another-to Kyoto and provide a counterpoint to what will happen in that meeting. Two papers relate directly to the Kyoto meeting. One of our editors-John Carman-offers a piece that connects two of the emergent themes of the conference but which do not appear to touch at the conference itself. In looking to see how the concept of sustainability can be applied in archaeological education in Universities, he explicitly links ideas likely to be present in Themes 01 (Development), 04 (Ethics), and 13 (Disaster) and no doubt others, with those of themes 08 and 09 on aspects of Education. He raises the challenge of how archaeologists of the future-those who attend in Kyoto as students-will respond to the challenge of creating and maintaining a sustainable future. The second paper in this short 'strand' develops a concern for students by offering a perspective on attending WAC in Kyoto from two such students-both of them current $\mathrm{PhD}$ researchers at the University of Birmingham in the UK, and both also with professional experience in the field, but deriving 
from very different backgrounds. In their joint paper, Sarah Howard and Malgorzata Trelka reflect on how their work brings them to Kyoto, the specific sessions in which they will take part, and what they each hope to gain from the wider encounter with archaeologists from across the globe that WAC offers.

The kind of content one can expect of Themes 03 (post-colonial experience) and 06 (regional archaeologies) is represented in Valence Silayo's paper on the connection between inter-ethnic violence in northern Tanzania and its colonisation by Europeans during the 19th and 20th centuries. The focus is less directly upon the activities of Europeans but much more upon local struggles for power and how these allowed Europeans to obtain dominance. Combining historical sources-especially oral testimony-with archaeological evidence, the paper emphasises WAC's commitment to relations within and between communities also evident in a number of sessions spread across various Themes.

Silvia Reis' contribution compares two quite different contexts in terms of how understandings of similar evidences from the past are incorporated within their different constructions of national identity. A 'shell mound' is a common feature of many coastal regions of the world but how they are understood as part of a national story can be very different. This paper focuses upon Brazil and Japan where they are seen very differently, in one as part of an anonymous 'distant' and alien past that does not relate to the present and in the other as part of a national story that has its roots in that distant past and in which these features play their part as evidence of ancestral presence. It reflects content in Themes 03 (post-colonial experience), 05 (comparative archaeologies), and 06 (regional archaeologies).

Katie Kirakosian's short story reflects aspects of a number of Themes, especially 01 (Development), 03 (post-colonial experience), 04 (ethics), 06 (regional archaeologies), 09 (theory for the future), and 12 (interactions). The story form allows for multiple voices to be heard in the complex framework of 'real-world' archaeology where archaeologists are also human beings with lives beyond the trench, having to make difficult ethical choices in engagement with others who may be very different from themselves, while working to agendas set by commercial rather than academic need. Although located firmly within a North American context, the content of the story should resonate with any of us who have ever worked in contract archaeology or dealt with a stakeholder community. It also represents WAC's and this journal's commitment to developing innovative approaches in all aspects of archaeology, including how it is written, and our equally strong commitment to students such as its author. 


\section{Archaeology and Politics}

All of our contributions of course reflect Theme 02 of the Congress, that archaeology is inevitably and unavoidably a political activity in itself while also operating within diverse and often challenging external political contexts. Meanwhile, politics in the rest of the globe continues to offer uncertainties that will have inevitable consequences for archaeology and archaeologists.

Recent Editorials have focused upon the depredations of ISIS (also known as Daesh) and similar organisations, but this summer's focus is on Europe where interesting things are happening. The narrow UK vote to leave the European Union will have consequences not only for British archaeologists but also for those with whom they plan to collaborate in Europe and elsewhere. The snag, of course, is that what the consequences will be are entirely unclear. Current advice is that it will be 'business as usual' for at least a while and possibly after too, but there is no guarantee of that and no real indication of what alternatives may be on offer. Quite apart from the specific arrangements that will need to be made with the EU, how these will impact upon relations with other countries and the specific form of individual bilateral agreements to be made consequent upon cancellation of agreements deriving from EU relations, all remain in the realm of the unknown. More immediate consequences are however evident: the creation of a new government comprising new individuals occupying key positions, an uncertain relationship for the UK government with its devolved regions-especially Scotland and Northern Ireland whose people voted to remain in the EU-and a rising cry even from some of those who voted to leave for the decision to be revisited because of the closeness of the vote and the apparent retreat by those who led the 'Leave' campaign from statements they made: all create vast uncertainties that will need to be faced.

Threats to stability on the eastern border of the EU may also play a part in our futures. The recent and ongoing conflict between Russia and Ukraine heightened tensions between Russia and the West. The most recent move in this dangerous game of military chess is the despatch to Poland and the Baltic States of 4000 NATO-especially the US and British-troops 'on exercise'. Not unexpectedly, the presence of new forces in a region produces a rash of rhetoric of the kind that inflames rather than calms. As one commentator has suggested, 'we have not been in such a dangerous place since Europe 1913 or 1939' (The Guardian 12/07/2016) and any student of the archaeology of conflict (see Theme 015 and sessions in Themes 05 and 06) knows what happened next on those occasions. Add to this the continuation of instability across the Middle East, uncertainties 
about the outcome of the US elections, the continuing violent activities of radical Islamic groups across the globe and especially in Europe, continuing tensions between the two Koreas, China, and Japan over disputed waters, and occasional strains between Latin American countries, and it is clear we live in increasingly 'interesting times'. Two events that took place during the writing of this Editorial confirm the latter: the use of a truck to kill scores of people and injure many more at a celebration in Nice; and the attempted coup in Turkey which-depending on your point of view-either indicates the strength of electoral democracies to overcome threats to their stability, or provides an opportunity for an already oppressive government (see Editorial April this year) to consolidate and extend their control. The detainment of thousands of Turkish citizens and restrictions placed upon others-including our academic colleagues-may give confirmation to the latter view of events there.

Quite what role archaeology can or should play in these developments is perhaps something we need to discuss during our time in Kyoto. We inevitably remain divided over attitudes towards engagement with the military, over the role of the private sector in archaeological work, over the appropriateness of relations with communities, and over how we should engage with our governments. On the other hand, we are a global discipline who meet amicably to discuss matters of common concern and humanity. Especially now, when many democratic countries are facing waves of political populism and many politicians appear morally weak, and when non-democratic regimes are placing increasing restrictions on human rights, it is necessary that the archaeological and wider academic communities promote their expertise and moral authority to support the freedom of people worldwide. As a voice for peace and stability we perhaps could be strong. As a voice for the unity of humankind we are strong. Forward to WAC in Kyoto!

John Carman

Jan Turek

July 2016 